\title{
Texts, Contexts and Readings in Postexilic Literature
}

\author{
Explorations into Historiography and Identity Negotiation in Hebrew Bible and \\ Related Texts \\ Ed. by Louis C. Jonker
}

[Texte, Kontexte und Lesarten. Untersuchungen zur Historiographie und Identitätsstiftung im Yehud der persischen Zeit.]

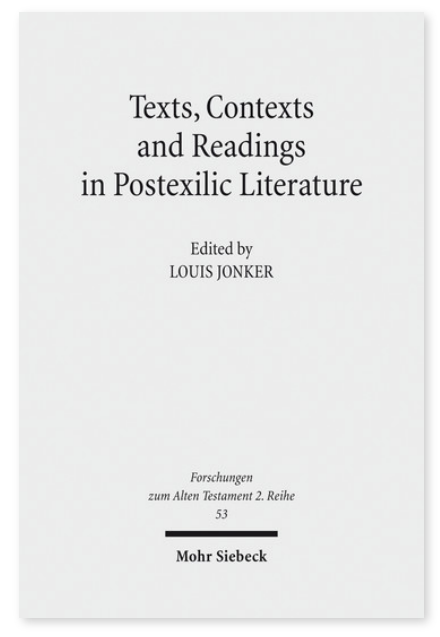

2011. XI, 317 Seiten. FAT II 53

ISBN 978-3-16-151852-2

DOI 10.1628/978-3-16-151852-2

eBook PDF $89,00 €$

ISBN 978-3-16-150975-9

fadengeheftete Broschur 89,00€
Veröffentlicht auf Englisch.

In Zeiten sozialgeschichtlicher Veränderungen steigt häufig das Interesse an der Geschichtsschreibung. Interesse an der Vergangenheit wird dann durch Prozesse der Identitätssuche und -stiftung ausgelöst, die eine Neuorientierung unter veränderten Umständen erleichtern. Die hebräische Bibel ist hierfür ein hervorragendes Beispiel, da sie viele historiographische Texte aus unterschiedlichen sozialgeschichtlichen Perioden enthält. Vom sechsten bis vierten Jahrhundert fanden im alten Israel tiefgreifende sozio-politische und sozio-religiöse Veränderungen statt. Diese Veränderungen bewirkten durch historiographische Literatur unterschiedliche Prozesse der Identitätsstiftung. Die Autoren der hier gesammelten Aufsätze untersuchen solche Texte und ihre Kontexte aus entsprechend turbulenten Zeiten und kommen so zu einem besseren Verständnis der dynamischen Beziehung zwischen der antiken historiographischen Literatur und Identitätsstiftung. Sie untersuchen auch, wie diese Literatur in heutigen Kontexten sozialgeschichtlicher Umbrüche interpretiert werden könnte.

\section{Inhaltsübersicht}

\section{Introduction}

Louis Jonker: Introduction. Reflecting on Historiography and Identity Negotiation - Robert Vosloo: The Writing of History as Remedy or Poison? Some Remarks on Paul Ricoeur's Reflections on Memory, Identity and »The Historiographical Operation« Exploring Texts and Intertexts

Gary Knoppers: Exile, Return, and Diaspora. Expatriates and Repatriates in Late Biblical Literature - Louis Jonker: Engaging with Different Contexts. A Survey of the Various Levels of Identity Negotiation in Chronicles - Ehud Ben Zvi: On Social Memory and Identity Formation in Late Persian Yehud. A Historian's Viewpoint with a Focus on Prophetic Literature, Chronicles and the Dtr. Historical Collection - Johann Cook: Contextuality in Wisdom Literature. The provenance of LXX Proverbs and Job as Case Studies

\section{Exploring Contexts}

Josef Wieshöfer: The Achaemenid Empire. Major Phases in State Formation and Features of the State - Oded Lipschits: A New Look on the Archaeology of Persian Period Judah - Izak Cornelius : »A Tale of Two Cities«. The Visual Symbol Systems of Yehud and Samaria and Identity / Selfunderstanding in Persian-period Palestine

Exploring Readings

Gerrie Snyman: Why Asa was not Deemed Good Enough. A Decolonial Reading of 2 Chronicles 14-16 - Makoshi Nzimande: Imbokodo Explorations of the Prevalence of Historical Memory and Identity Contestations in the Expulsion of the Nāšîm Nokriyyōt in Ezra 9-10

Conclusion

Louis Jonker: Conclusion. Chronicles as »Reforming History«

Louis C. Jonker Born 1962; BA, HonsBA, MA, BTh, LicTheol and DTh from University of Stellenbosch; since 2010 Professor in Old Testament at the University of Stellenbosch; Congress Secretary of the 2016 meeting of the International Organization for the Study of the Old Testament (IOSOT).

Jetzt bestellen:

https://mohrsiebeck.com/buch/texts-contexts-and-readings-in-postexilic-literature-9783161518522?no cache=1 order@mohrsiebeck.com Telefon: +49 (0)7071-923-17

Telefax: $+49(0) 7071-51104$ 